\title{
Design and Validation of Lesson Plan Development in Materials Technology Courses with an Outcome-Based Education Approach
}

\author{
Sutrisno ${ }^{1}$ Siti Zulfa Yuzni ${ }^{1}$ Nono Sebayang ${ }^{1}$ Mena Fadillia Lukman ${ }^{1}$ Kinanti \\ Wijaya $^{1, *}$ Iswandi Idris ${ }^{2}$ Ruri Aditya Sari ${ }^{2}$ Agnita Yolanda ${ }^{3}$ \\ ${ }^{I}$ Engineering Faculty of Universitas Negeri Medan, Jalan Willem Iskandar Psr.V, Medan Estate, Indonesia \\ ${ }^{2}$ Politeknik LP3I Medan, Jalan Sei Serayu No.48D, Indonesia \\ ${ }^{3}$ Universitas Medan Area, Jalan Kolam No.1, Kenangan Baru, Medan Estate, Indonesia \\ *Corresponding author. Email: kinanti.w@ unimed.ac.id
}

\begin{abstract}
The realization of World Class University is included in the Indonesian government program. The first step to achieve equality in the quality of National and International Education is to adopt the existing curriculum with Outcome-based Education (OBE) principles. The OBE principle is a reference for assessing academic service appraisal institutions at the international level. Therefore, this research was conducted as the first step in achieving equality in the quality of international level in the Department of Engineering, Faculty of Engineering, Universitas Negeri Medan. This research involved 7 validator from public and private institution and practice professional. This research using 12 aspects as an indicator to assess the achievement of OBE approach are completeness of the Semester Study Plan elements, clarity of learning plan writing, courses learning outcomes achievement to study program graduates', measurable of Courses Learning Outcomes description, the alignment of Courses Learning Outcomes with the material and learning model used, the used of Higher Order Thinking Skill (HOTS), the conformity for estimates time allocation with the activities carried out, the use of the language understanding and clearness. The results showed that the lesson plan of materials technology course had reached outcome-based education approach.
\end{abstract}

Keywords: Outcome-based education, Design and validation, Lesson plan, Technology course.

\section{INTRODUCTION}

Assessment of the quality of education in a university is regulated in Ministerial Regulation Number. 3 of 2020 which is listed in the National Higher Education Standards. The current government prioritizes equalizing the quality of education in Indonesia with several other countries. The rules of the Chamber of Commerce and Industry state that the target for the absorption of graduates is national and international. The average absorption of graduates in Indonesia is only around 40\%, for this reason it is necessary to equalize the quality of education in higher education, namely improving the quality of human resources, curriculum management and infrastructure [1]. Currently, the Indonesian government has prepared the The Indonesian National Qualifications Framework Independent Learning-Independent Campus
(MBKM) curriculum which aims to improve the quality and relevance of higher education graduates.

The Department of Building Engineering Education has implemented the The Indonesian National Qualifications Framework, Independent LearningIndependent Campus curriculum, but there are several obstacles related to the deepening of Courses Learning Outcomes that must be adjusted to the competency needs of the business and industrial world through link and match. This is in accordance with the results of observations which show that the determination of Courses Learning Outcomes at Semester Lesson Plan is still in the Good category although it is still necessary to revitalize courses learning outcomes in the Department of Building Engineering in order to achieve graduate competency standards. 
Universitas Negeri Medan has a vision that is to become a World Class University, and in order for this vision to be achieved, several improvements are needed, including the Courses Learning Outcomes revitalization program. This vision is actually the vision of the Indonesian Government Program as regulated in Ministry of Education and Culture Number 754/P/2020 concerning Main Performance Indicators of State University and Higher Education Service Institute [2].

One of the first steps in realizing equality in the quality of education is the principle of Outcome-based education (OBE). This OBE principle focuses on learning outcomes, curriculum design based on outcomes, alignment between the assessments of the learning process and learning outcomes, creating a conducive learning environment and implementing the PDCA (Plan, Do, Check, Act) cycle [3]. This principle is a reference for assessing academic service appraisal institutions at the international level. Therefore, this article is the first step in achieving quality equality at the international level in the Department of Building Engineering Education, Faculty of Engineering, and Universitas Negeri Medan.

This study aims to find out how to develop OBEbased Course Learning Outcomes in theoretical subjects in the Department of Building Engineering and to design the substance of the OBE-based Semester Study Plan in the Department of Engineering Education based on OBE principles.

This research is a research design of OBE-based learning outcomes in theoretical subjects that will contribute to special colleges in the Department of Building Engineering Education in revitalizing the substance of the OBE-based Semester Learning Plan so that it becomes the first step for study programs in applying for recognition at the international level through international accreditation. In addition, this research can also be the basis for the development of Course Learning Outcomes in universities with the OBE paradigm. Outcome-based education begins with a clear picture of the main abilities that can be done by study program graduates. The concepts and principles of Education based on learning outcomes are:

\subsection{Focusing on learning outcomes}

The formulation of learning outcomes begins with the learning outcomes of graduates at the study program level to be reduced to learning outcomes for subjects.

\subsection{Achievement-based curriculum design}

The curriculum is prepared by determining learning outcomes first and then setting the model and assessment system. Next, design the learning process.

\subsection{Alignment between assessment, learning process, and learning achievement}

There needs to be a constructive alignment between the assessment and learning process with the established Courses Learning Outcomes. The alignment process can use a mapping between the assessment and Courses Learning Outcomes and between the learning process and Courses Learning Outcomes.

\subsection{Creating a conducive learning environment}

A conducive learning environment in the learning process includes the diversity of learning resources, materials that follow the development of knowledge and technology, as well as adequate facilities both in terms of quantity and quality.

\subsection{Application of the P-D-C-A cycle}

There is a continuous process from planning, implementation, monitoring, to development. In this case, the quality assurance agency has a role in ensuring the cycle.

The National Accreditation Board for Higher Education, figure 1 explains the concept of OBE-based Semester Lesson Plan.

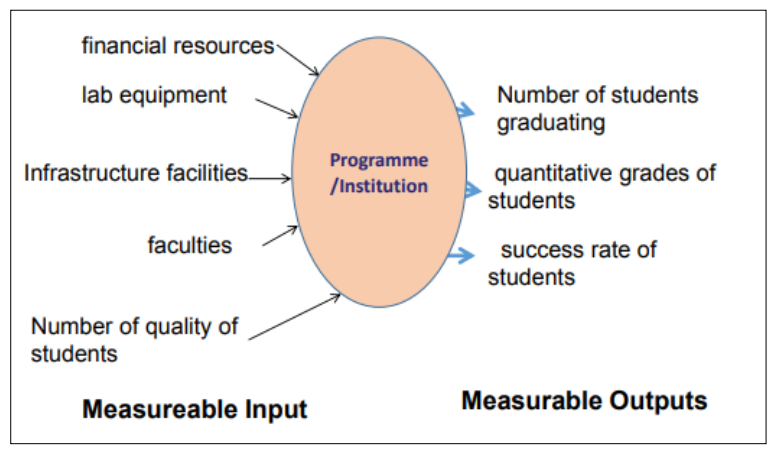

Figure 1 Semester Lesson Plan based on OBE.

In essence, OBE integrates a number of processes including curriculum design, process assessment and teaching and learning methods that focus on what students can do. OBE emphasizes that learning outcomes can be met in terms of knowledge, skills and attitudes according to social, economic and academic cultural conditions [4].

\section{METHOD}

The research was conducted in the even semester of 2020/2021 on theoretical subjects in the field of building engineering. The type of this research is research and development. According to Aminah and Candra [5] that research and development is a process or steps to develop a product or improve an existing product. The research 
and development used to produce certain products and test the effectiveness of these products with the aim of producing new products through the development process [6]. There are 4 stages in the ADDIE model development research, namely the analysis, design, development, implementation, and evaluation stages. Figure 2 showed the procedure of development an OBEbased on Semester Lesson Plan.

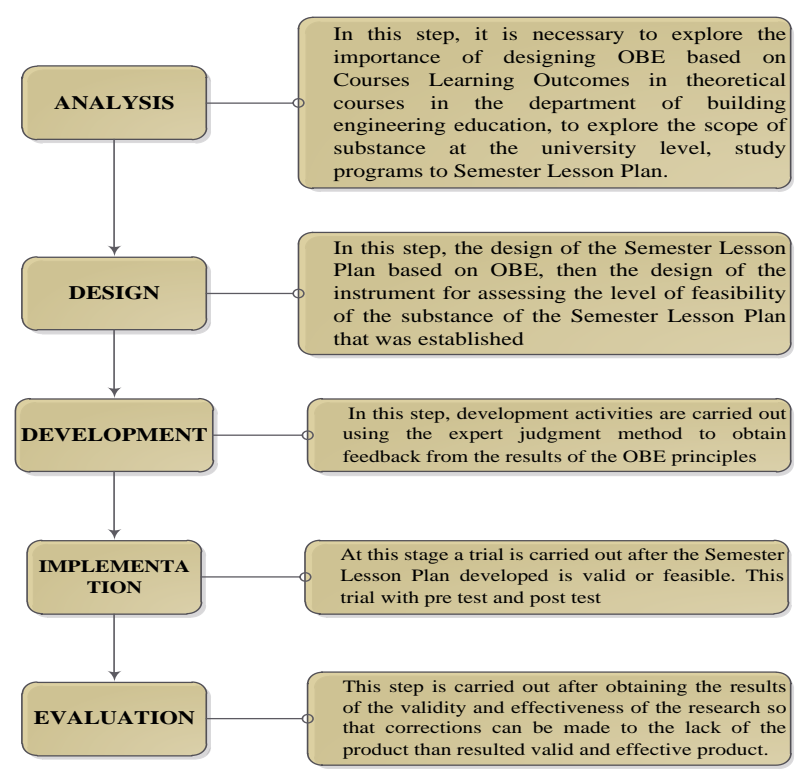

Figure 2 Flow Chart Development of Semester Lesson Plan.

\section{VALIDITY TEST}

The test that is answered to have student learning outcomes is a test that has been tested for validity. To test the validity of the test, use the formula of Biserial Point Correlation [6] with the following formula:

$$
r p b i=\frac{M p-M t}{S D t} \sqrt{\frac{p}{q}}
$$

Information:

Rpbi $=$ biserial point correlation coefficient

$\mathrm{Mp}=$ Mean score of the subjects that answered correctly the item that was looking for correlation

Mt = Mean total score (Average score of all test takers)

SDt $=$ Standard deviation total score

$\mathrm{P} \quad=$ Proportion of Subjects who answered the item correctly

$\mathrm{Q} \quad=1-\mathrm{p}$

To find the value of $\mathrm{p}$ :

$\mathrm{P}=\underline{\text { (The total number of students who answered correctly) }}$

(The total number of students)
To find the value of Mt:

$M t=\frac{\sum \mathrm{Xt}}{\mathrm{N}}$

To find the value of SDt:

$S D t=\sqrt{\frac{\sum \mathrm{Xt}^{2}}{\mathrm{~N}}-\left(\frac{\sum \mathrm{Xt}}{\mathrm{N}}\right)^{2}}$

Because if rcount $>$ rtable then the instrument is valid, otherwise if rcount < rtable it means the question is invalid, then the question must be revised or not used. Table 1 showed the score interpretation of validation [7].

Table 1 Score Interpretation of Validation.

\begin{tabular}{ccc}
\hline Interval & Category & Explanation \\
\hline $3.5 \leq \mathrm{V} \leq 4.0$ & $\begin{array}{c}\text { Very } \\
\text { Worthy }\end{array}$ & $\begin{array}{c}\text { Can be continued } \\
\text { without revision } \\
\text { Can be continued } \\
\text { with revision } \\
\text { Can be continued } \\
\text { with many } \\
\text { revisions }\end{array}$ \\
$3.5 \leq \mathrm{V} \leq 4.0$ & Worthy & Worthy \\
$2.9 \leq \mathrm{V} \leq 3.4$ & Not & $\begin{array}{c}\text { Can not be } \\
\text { continued }\end{array}$ \\
\hline
\end{tabular}

\section{RESULTS AND DISCUSSION}

In the analysis step, a search is carried out on the importance of designing an OBE-based Courses Learning Outcomes in a theoretical course in the Department of Building Engineering Education. Conducting exploration of the scope of substance at the university level, study program to Semester Lesson Plan. The results of analysis, this building engineering study program conducted a focus group discussion (FGD) to analyze the importance of preparing an OBE-based on Semester Lesson Plan.

In the design step of Semester Learning Plan based on OBE (Table 2), then designs an instrument for assessing the feasibility level of the Semester Learning Plan substance that is built. In this step, the building engineering study program has developed an instrument to measure the feasibility of an OBE-based on Semester Learning Plan.

Table 2 The Instruments of Design Stage.

\begin{tabular}{cl}
\hline Number & \multicolumn{1}{c}{ Aspects } \\
\hline 1 & $\begin{array}{l}\text { Completeness of Semester Learning Plan } \\
\text { (identity, learning objectives, material, } \\
\text { methods, learning activities, learning } \\
\text { resources, and assessments) }\end{array}$ \\
2 & $\begin{array}{l}\text { Clarity of Semester Learning Plan writing } \\
\text { (numbering, type, and font size) }\end{array}$ \\
3 & $\begin{array}{l}\text { Courses Learning Outcomes with the } \\
\text { achievement of study of graduates of the } \\
\text { Study Program }\end{array}$ \\
\hline
\end{tabular}




\begin{tabular}{cl}
\hline 4 & $\begin{array}{l}\text { Course Learning Outcomes description at } \\
\text { Course Learning Outcomes can be } \\
\text { measured or observed }\end{array}$ \\
5 & $\begin{array}{l}\text { Course Learning Outcomes alignment with } \\
\text { learning material. }\end{array}$ \\
6 & $\begin{array}{l}\text { Course Learning Outcomes alignment with } \\
\text { models/learning methods used. } \\
\text { Course Learning Outcomes alignment } \\
\text { with the form of assessment and } \\
\text { evaluation }\end{array}$ \\
8 & $\begin{array}{l}\text { Course Learning Outcomes has a high- } \\
\text { level thinking taxonomy }\end{array}$ \\
9 & $\begin{array}{l}\text { Conformity for estimates of time allocation } \\
\text { with activities carried out } \\
\text { The use of language is in accordance with } \\
\text { a good and correct Indonesian rule }\end{array}$ \\
11 & $\begin{array}{l}\text { The language used does not cause a double } \\
\text { understanding } \\
\text { The language used short and clear }\end{array}$ \\
\hline
\end{tabular}

In the year of development, it was carried out using the Expert Judgment (Table 3) method to obtain from the principal expert; this stage was carried out by distributing questionnaires to OBE experts to receive the results of the assessment. The following is the answer to experts related to Semester Learning Plan based on OBE. Based on Table 3, it is known on average the team of experts assesses both the assessment instrument of OBE-based Semester Learning Plan.

At the implementation stage, the Semester Learning Plan trial was conducted by applying the level of validity of the instrument that was assessed by experts (Table 4).

At the evaluation stage, Course Learning Outcomes using OBE approach is evaluated against the effectiveness of assessment and validity. This OBEbased Course Learning Outcomes is considered quite good and effective because OBE has several principles as follows [8]:

\subsection{Focusing on learning achievements}

The formulation of learning achievements began with graduate learning achievements at the study level to be reduced to become the achievement of courses learning.

\subsection{Designing curriculum based on achievements}

The curriculum is arranged by setting learning achievements first then set the model and system assessment. Furthermore, design the learning process. A job between assessment, learning processes, and learning achievements.

Table 3 Expert Assessment.

\begin{tabular}{|c|c|c|c|c|c|c|c|c|c|}
\hline \multirow{2}{*}{ Aspects } & \multicolumn{7}{|c|}{ Validator } & \multirow{2}{*}{ Mean } & \multirow{2}{*}{ Result } \\
\hline & 1 & 2 & 3 & 4 & 5 & 6 & 7 & & \\
\hline $\begin{array}{l}\text { Completeness of Semester Learning Plan } \\
\text { (identity, learning objectives, material, } \\
\text { methods, learning activities, learning } \\
\text { resources, and assessments) }\end{array}$ & 5 & 5 & 5 & 4 & 5 & 4 & 5 & 4.71 & Very Good \\
\hline $\begin{array}{l}\text { Clarity of Semester Learning Plan writing } \\
\text { (numbering, type, and font size) }\end{array}$ & 5 & 5 & 5 & 5 & 5 & 4 & 4 & 4.71 & Very Good \\
\hline $\begin{array}{l}\text { Courses Learning Outcomes with the } \\
\text { achievement of study of graduates of the }\end{array}$ & & & & & & & & & \\
\hline Study Program & 4 & 5 & 5 & 4 & 4 & 5 & 4 & 4.43 & Very Good \\
\hline $\begin{array}{l}\text { Course Learning Outcomes description at } \\
\text { Course Learning Outcomes can be }\end{array}$ & & & & & & & & & \\
\hline measured or observed & 4 & 5 & 5 & 4 & 5 & 5 & 4 & 4.57 & Very Good \\
\hline $\begin{array}{l}\text { Course Learning Outcomes alignment } \\
\text { with learning material. }\end{array}$ & 4 & 5 & 5 & 4 & 5 & 4 & 4 & 4.43 & Very Good \\
\hline $\begin{array}{l}\text { Course Learning Outcomes alignment } \\
\text { with models/learning methods used. }\end{array}$ & 5 & 5 & 4 & 5 & 5 & 4 & 3 & 4.43 & Very Good \\
\hline $\begin{array}{l}\text { Course Learning Outcomes alignment } \\
\text { with the form of assessment and } \\
\text { evaluation }\end{array}$ & 4 & 5 & 5 & 5 & 5 & 4 & 3 & 4.43 & Very Good \\
\hline $\begin{array}{l}\text { Course Learning Outcomes has a high- } \\
\text { level thinking taxonomy }\end{array}$ & 5 & 5 & 4 & 4 & 5 & 5 & 3 & 4.43 & Very Good \\
\hline Conformity for estimates of time & & & & & & & & & \\
\hline $\begin{array}{l}\text { allocation with activities carried out } \\
\text { The use of language is in accordance with }\end{array}$ & 4 & 5 & 4 & 5 & 3 & 5 & 4 & 4.29 & Very Good \\
\hline a good and correct Indonesian rule & 4 & 5 & 5 & 5 & 5 & 4 & 4 & 4.57 & Very Good \\
\hline $\begin{array}{l}\text { The language used does not cause a } \\
\text { double understanding }\end{array}$ & 5 & 5 & 4 & 5 & 5 & 4 & 3 & 4.43 & Very Good \\
\hline The language used short and clear & 5 & 5 & 5 & 5 & 5 & 4 & 3 & 4.57 & Very Good \\
\hline
\end{tabular}


Table 4 Validity Test.

\begin{tabular}{cccccc}
\hline & $\begin{array}{c}\text { Scale Mean } \\
\text { if Item } \\
\text { Deleted }\end{array}$ & $\begin{array}{c}\text { Scale } \\
\text { Variance if } \\
\text { Item Deleted }\end{array}$ & $\begin{array}{c}\text { Corrected } \\
\text { Item-Total } \\
\text { Correlation }\end{array}$ & $\begin{array}{c}\text { Cronbach's } \\
\text { Alpha if } \\
\text { Item Deleted }\end{array}$ & Result \\
\hline $\mathbf{1}$ & 103.2857 & 102.238 & 0.519 & 0.763 & Valid \\
$\mathbf{3}$ & 103.2857 & 94.905 & 0.791 & 0.738 & Valid \\
$\mathbf{4}$ & 103.5714 & 98.952 & 0.322 & 0.753 & Valid \\
$\mathbf{5}$ & 103.4286 & 96.952 & 0.516 & 0.746 & Valid \\
$\mathbf{6}$ & 103.5714 & 95.619 & 0.647 & 0.741 & Valid \\
$\mathbf{7}$ & 103.5714 & 89.952 & 0.810 & 0.723 & Valid \\
$\mathbf{8}$ & 103.5714 & 88.619 & 0.907 & 0.718 & Valid \\
$\mathbf{9}$ & 103.5714 & 91.952 & 0.669 & 0.731 & Valid \\
$\mathbf{1 0}$ & 103.7143 & 101.905 & 0.612 & 0.766 & Valid \\
$\mathbf{1 1}$ & 103.4286 & 94.952 & 0.713 & 0.739 & Valid \\
$\mathbf{1 2}$ & 103.5714 & 89.952 & 0.810 & 0.723 & Valid \\
Total & 103.4286 & 88.619 & 0.907 & 0.718 & Valid \\
\hline & 54.0000 & 25.667 & 1.000 & .866 & \\
\hline
\end{tabular}

\subsection{Constructive harmony}

Constructive harmony is needed between the assessment and learning process with the established Course Learning Outcomes. Alignment process can use mapping between assessments with Course Learning Outcomes and between the learning process with Course Learning Outcomes.

\subsection{Creating a conducive learning environment}

The conducive learning environment in the learning process includes the diversity of learning resources, the material that follows the development of knowledge and technology, as well as maintained facilities in terms of number and quality.

\subsection{Application of P-D-C-A Cycle}

There is a continuous process ranging from planning, implementing, monitoring, to its development. In this case the Quality Assurance Institution has a role in guaranteeing the cycle [8].

This OBE is considered very effective, because it has several advantages rather than the usual Semester Learning Plan, this result was similar to Darmalaksana [9] with the title of implementation of the RPKPS Research Methods OBE-based research methods on the SKL and the Bachelor of the Bachelor of the Hadith Sciences study program revealed the evaluation results from the OBE-based RPCS applied for 1 semester. The method of this research is qualitative through literature studies. This study concluded that the successful implementation of OBE-based RPKPS was played greater by the readiness factor of the study and the implementation of the feedback on the stages of student training results which was oriented to improve the quality of the final training results. This study recommends the preparation of the OBE-based Semester Learning
Activity Program Plan in curriculum program courses in the PTKI environment.

This is result was similar to Alimudin [10] with a strategy to develop student learning achievements through the internalization of university values by mapping the basic character of students and educational assessments, directing them to the expected learning outcomes of the graduate learning achievement derivative. Study program; providing and spiritual students; maintain good communication between students with lecturers during the learning process; and do edutainment learning methods with a clear and transparent assessment system. The research method used is a participatory study. Table 5 showed the comparison of normal Semester Lesson Plan and OBE Semester Lesson Plan.

Table 5 Comparison of non-OBE Semester Lesson Plan and OBE Semester Lesson Plan.

\begin{tabular}{|c|c|}
\hline Non-OBE & OBE \\
\hline $\begin{array}{l}\text { - Focus on Learning } \\
\text { Materials }\end{array}$ & $\begin{array}{l}\text { - Focus on learning } \\
\text { outcomes }\end{array}$ \\
\hline $\begin{array}{l}\text { Curriculum Design } \\
\text { based on Learning } \\
\text { Materials }\end{array}$ & $\begin{array}{l}\text { - Outcome-based } \\
\text { curriculum design }\end{array}$ \\
\hline $\begin{array}{l}\text { Course Learning } \\
\text { Outcomes and } \\
\text { Process sometimes } \\
\text { don't align }\end{array}$ & $\begin{array}{l}\text { - } \text { Alignment of } \\
\text { CPMK and } \\
\text { Learning Process }\end{array}$ \\
\hline $\begin{array}{l}\text { - Not based on } \\
\text { Learning } \\
\text { Environment/Acade } \\
\text { mic Atmosphere }\end{array}$ & $\begin{array}{l}\text { - Creating a } \\
\text { conducive } \\
\text { learning } \\
\text { environment }\end{array}$ \\
\hline $\begin{array}{l}\text { - Not PDCA cycle } \\
\text { but still focused on } \\
\text { learning materiall. }\end{array}$ & $\begin{array}{l}\text { - Application of the } \\
\text { P-D-C-A . cycle }\end{array}$ \\
\hline
\end{tabular}




\section{CONCLUSION}

Based on the results and discussion, it can be concluded that the Outcome Base Education approach in Semester Lesson Plan validation is feasible to be developed because it has a very feasible validation level so that the building engineering department can implement this Semester Lesson Plan for curriculum development in the future.

\section{ACKNOWLEDGMENTS}

This research is a collaboration between LPPM and the Department of Building Engineering, Faculty of Engineering, Universitas Negeri Medan with contract number 0099/UN33.8/PL-PNBP/2021 on 27 Mei 2021.

\section{REFERENCES}

[1] L. Moerdijat, Permasalahan Pendidikan Vokasi di Indonesia (Pustaka Lestari), 2020. Retrieved from: https://lestarimoerdijat.com/pustakalestari/read/202 0/09/10/950/Permasalahan-Pendidikan-Vokasi-diIndonesia

[2] Kemendikbud No. 754/P/2020 Concerning Main Performance Indicators of State University and LLDIKTI.

[3] P. UGM, Outcome Base Education (OBE), Pusat Inovasi dan Kajian Akademik Universitas Gajah Mada, Yogyakarta, 2018.

[4] H. Wahyudi, I.A. Wibowo, Inovasi dan Implementasi Model Pembelajaran Berorientasi Luarab (Outcome-Based Education, OBE) dan Washington Accord di Program Studi Teknik Mesin Universitas Mercu Buana, Journal of Mechanical Engineering, vol. 07, 2018, pp. 50-56. DOI: https://dx.doi.org/10.22441/jtm.v7i2.4214

[5] A.C.N. Aminah, Pengembangan Mobile Learning Berbasis Android Pada Materi Wirausaha Mata Pelajaran Kewirausahaan Di Kelas XI SMK N 1 Kalasan, Yogyakarta State University, Yogyakarta, 2017.

[6] Sugiyono, Statistika untuk Penelitian, 23rd Eds, Alfabeta, Bandung, 2013.

[7] D.A.T. Soffa, S. Poedjiastoeti, P. Setiarso, Design and Validation Of Teaching Instruments Oriented Problem Solving to Train Students Metacognitive Skills, Advances in Engineering Research, vol. 171, 2018, pp. 129-133. DOI: https://dx.doi.org/10.2991/snk-18.2018.31

[8] K.W. Hariapsari, Tukiran, E. Sudibyo, Validity of Teaching Materials Based on Socio-Scientific Issues Approach on The Topic of Vibration, Waves, and Sound. Validity of Teaching Materials Based on
Socio-Scientific Issues Approach on The Topic of Vibration, Waves, and Sound, IOP Conference Series: Journal of Physic, vol. 1108, 2018, pp. 1-6. DOI: $\quad$ http://dx.doi.org/10.1088/17426596/1108/1/012034

[9] W. Darmalaksana, Implementasi RPKPS Mata Kuliah Metode Penelitian Berbasis OBE pada SKL dan CPL Jenjang Sarjana Prodi Ilmu Hadis, Jurnal Ushuluddin UIN Sunan Gunung Djati Bandung, 2020, pp. 1-16.

[10] A. Alimudin, Strategi Membangun Capaian Pembelajaran Mahasiswa Melalui Internalisasi Nilai-Nilai Perguruan Tinggi, Jurnal Manajemen Dan Pendidikan Islam, vol. 3, 2017, pp. 64-80. DOI: http://dx.doi.org/10.26594/dirasat.v3i1.1008 